\title{
Hommage à Bernard Juillerat
}

\section{(2) OpenEdition \\ Journals}

Édition électronique

URL : http://journals.openedition.org/jso/1106

DOI : 10.4000/jso.1106

ISSN : 1760-7256

Éditeur

Société des océanistes

\section{Édition imprimée}

Date de publication : 1 décembre 2006

Pagination : 224

ISSN : 0300-953x

\section{Référence électronique}

"Hommage à Bernard Juillerat », Journal de la Société des Océanistes [En ligne], 122-123 | Année 2006, mis en ligne le 08 avril 2008, consulté le 15 septembre 2020. URL : http://journals.openedition.org/jso/ 1106

\section{(c) Tous droits réservés}


dance. Ratu Mara, Premier ministre des Fidji, disait de Carlton Skinner : "C'est un homme de conviction et non d'ambition ». Il fut en effet toujours prompt à susciter le choix de ressortissants des États du Pacifique pour occuper des postes de responsabilités dans les institutions régionales et internationales. C'est ainsi, sur sa proposition, qu'en octobre 1969 fut nommé, comme premier secrétaire de la Commission du Pacifique Sud originaire d'un État du Pacifique, Harris Moor des Samoa occidentales.

Carlton Skinner appartint quelques années à la Société des Océanistes où il fit une conférence remarquée sur les États du Pacifique qu'il nommait le «Quatrième monde ». Il publia en 1997 un ouvrage intitulé After Three Centuries: Representative Democraty and a Civilian Government for Guam. Cet homme, d'une rare sensibi-

\section{Hommage à Bernard Juillerat}

Nous venons d'apprendre, avant de mettre sous presse ce numéro, le décès de notre collègue Bernard Juillerat survenu le mardi 6 juin, à la suite d'une longue maladie. Ses obsèques ont eu lieu le lundi 12 juin au crématorium du cimetière du Père-Lachaise.

Après avoir travaillé en Afrique au NordCameroun, Bernard Juillerat avait choisi de conduire des recherches chez les Yafar de Papouasie Nouvelle-Guinée. Il en rapporta une collection ethnographique très bien documentée pour le musée de l'Homme et rédigea de nombreuses publications dont plusieurs ouvrages sur lité et doté d'un grand sens de l'humour, s'est éteint à l'âge de 91 ans dans sa ville natale de Boston le 22 juin 2004. Il resta soucieux, jusqu'à ses derniers jours, des problèmes des États du Pacifique, fidèle à ses principes d'égalité, d'antiracisme et de justice. Sur le carton d'invitation du Memorial Service organisé en sa mémoire le 19 septembre 2005 à Hagatna, le gouverneur de Guam, Felix P. Camacho, a écrit cette épitaphe éloquente qui résume très bien la vie de Carlton Skinner :

"He was a man of great integrity fighting injustice wherever he found it, wanting everyone to have his chance.»

Merto Theresa, 2004 (20 août). " Skinner, first U.S. civilian governor of Guam, dies », Pacific Daily News.

cette société du Sépik. De 1977 à 1982, Bernard Juillerat appartint au bureau de notre société. Il y participa activement en tant que rédacteur du JSO. Le JSO publiera dans son prochain numéro un hommage retraçant la carrière et l'œuvre de ce grand chercheur.

Divers membres de notre conseil d'administration et de nombreux collègues ayant connu et apprécié Bernard Juillerat se sont prononcés pour l'organisation d'une journée en sa mémoire. Celle-ci pourrait avoir lieu au début de l'année 2007 dans les nouveaux locaux du musée du quai Branly. 